\title{
Ideology and Action Programme of the Swadeshi Movement in Tamil Nadu
}

\author{
Dr. M. Kasthuri \\ Assistant Prof.Dept.Of HistoryBharathidasan Govt. College for Women (Autonomous)Puducherry-605003.
}

\begin{abstract}
Nationalism in India, though universally affecting the whole of the sub-continent, was an uneven development, originating indifferent parts of India at different points of time. The uniqueness of the Nationalist Movement in Tamil Nadu was due to the Swadeshi and boycott ideology and political activities of V.O. Chidambaram pillai and accompanied with other nationalist.

Swadeshi meant not only use of one's own goods but also more significantly the revival of the glorious Seafaring tradition of the Thenpandi of Tirunelvelly district and boycott was both an economic and emotional weapon to free India of the unwanted presence of the foreigner.

VOC's ideology ofSwadeshi and boycott led to the birth of the Swadeshi Steam Navigation Company against the British Indian Steam Navigation Company and mobilising the workers of Coral Mills in Tirunelvelly. This brought him in to increasing conflict with the British Raj and proves that the British were not needed in India.

In addition this paper express briefly about SubramaniaBharathi and Subramania Siva a wellknownSwadeshi activists and supporter of VOC.

Key words,

Swadeshi and boycott ideology of VOC-

Revivalist and Nativist sentiments of VOC-

Birth of Swadeshi Steam Navigation Company-

Labour unrest and Swadeshi-

VOC with SubramaniyaBharathi and Subramaniya Siva-
\end{abstract}

\section{Introduction}

Nationalism in India was an outcome against the oppressive and suppressive policies of the British Government. Nationalist sentiments, though uniform in their sources of origin, varied greatly from region to region in their modes of expression because of regional disparities and the cultural diversity of India.

In Tamil Nadu, as in other parts of India, the expression of opposition to British rule was due to the emergence of major political figures such as Veerapandiakattapomman,C.Subramania Iyar, V.O.ChidambaramPillai and SubramaniaBharathi were influenced by the Bengali nationalist.

Madras on the Coramandel Coast was the first territorial acquisition of the British in 1639, establishedas a trading post in the seventeenth century it gradually grew into the Madras Presidency in the course of the eighteenth century. This first settlement of the British was also the first centre of revolt against the political activities of the British.

The Tamil land especially Thenpandi or Pandinadu in the extreme south, referred to as the Tirunelvelly district in the British records, possesses an ancient andglorious history. In the later part of the eighteencentury, it had fostered a movement of resistance to British rule spearheaded by Kattabomman of Panchalankurichy fame. He was publicly hanged at Kayattar on 16 October 1799. The second attempt was made at Vellore in 1806. Thus thepoligars of Tirunelvelly and the sepoys of Vellore were ruthlessly punished by the colonial Government.V.O. Chidambaram Pillai, a native of Tirunelvellydistrict wasexposed to the folklore at a very young age and drew great inspiration from the fallen heroes of Tirunelvelly.

In the wake of the partition of Bengal in 1905, the extremists gained ground and started a new movement.Everywhere in British India the new movement hadcomprised young men bound together bythe ideology opposition to the British. In Tamil Nadu V.O.ChidambaramPillai of Ottapidaram, along with C. SubramaniaBharathi, Subramaniya Siva V. ChakkaraiChetti, Ethiraj, SurendranathArya, S. Srinivasachari,S.N Thirumalachari and M. P. Tirumalachari constituted the core group of the new movement.However, V.O. Chidambaram Pillai practically put to experiment the Swadeshi ideology and stoodabove other leaders of the same period. An attempt has been made in this paper to throw light on the roleof V.O. Chidambaram Pillai in the National Movement in Tamil Nadu and his collaboration with the likeminded leaders of Tamil region. Mostly contemporary sources are used in the preparation of this paper.

Early Career 
ValliyappanOlaganathan Chidambaram Pillai, popularly known by his initials, V.O.C, VaVoo.Cee, KappalOottiyaTamilzhan, was an Indian freedom fighter born on $5^{\text {th }}$ September 1872 , to an eminent lawyer OlaganathanPillai and Paramayi in Ottapidaram, Tinnevelly district of Tamil Nadu ${ }^{1}$. After completing his school life inOttapidaramandTinnevelly, he completed law in 1895, at Tiruchirapalli.

In 1900, V.O. ChidambaramPillai had moved to Tuticorin and set up legal practice there. Whenever he was free, he went for long walks along the seashore. He loved the sea. The light of the vast expanse of blue, broken by white foamy waves, evoked in him sublime thoughts. So his mind went back to the glories of ancient India and created in him a deep desire to join the Nationalist Movement ${ }^{2}$.

\section{Swadeshi Ideology}

The ideology of nationalism unified the different lingo-cultural communities of India and it became an effective weapon in the twentieth century for the Indians to fight colonial tyranny and oppression. Swadeshiand boycott, the twin aspects of the nationalist ideologywere so appealing to Chidambaram that he sought to pursue these twin objectives through his new enterprise.

The whole of the Tinnevelly district was inflamed by his fire ideology and inspired by revivalistic and nativistic sentiments. A revivalistic ideology aimed "to return to a former era of happiness, to restore a golden age" and nativism aimed "to purge the society of unwanted aliens, of cultural elements of foreign origin ${ }^{3}$. Swadeshi meant for him the revival of the glorious sea faring traditions of the Tamils and boycott was both an economic and emotional weapon to free India of the unwanted presence of the foreigner.

\section{Programme of Swadeshi Movement}

The Partition of Bengal in July 1905, intensified feeling of extreme nationalism in India. The Indian National Congress and nationalists of Bengal firmly opposed the partition. BalGangadharTilak played a leading role in spreading the message of Swadeshi- use of Indian goods and boycott of foreign goods. In the wake of the ant partition agitation a Swadeshi movement emerged in the South and Chidambaram found himself a part of this new movement.

In1906,V.O.Chidambarampillai went to the residence of Thirumalaichari in Madras, the publisher of the "India" and expressed his desire to meet SubramaniaBarathi ${ }^{4}$.HewasIntroducedbyThirumalachari to SubramaniaBharathi, editor of "India". Like Chidambaram PillaiBarathi was also a native of Tinnevelly district, naturally they became close to each other. Chidambaram Pillai accompanied Bharathi to the Marina Beach where they sat hours together and shared their emotions and feelings about the subjugation of India and her degradation under the British ${ }^{5}$. Bharathi talked at length on the patriotism of the people of Bengal and about Bepin Chandra Pal, the fiery nationalist from Bengal.V.O Chidambaram Pillaiwas so inspiredby the example of Bepin Chandra Pal that he could feel the fire of patriotism stirred in his heart.

During one of his visits to Madras in 1906, Chidambaram metSwamiRamakrishnananda, a disciple of SwamiVivekananda in the Ramakrishna Mutt. An ardent exponent of Swadeshi, Ramakrishnananda asked Chidambaram what efforts he had undertaken to promote Swadeshi. To his questionV.O.Chidambaram made a philosophic response by stating that any effort was in vain in a life of illusion. Realising that Chidambaram was in a state of disillusionment, Ramakrishnananda told him that Swadeshi was the only panacea ${ }^{6}$.Thus, the seed of Swadeshiwas planted in the fertile mind of young Chidambaram. That was politically alive and spiritually fortified, burning equally with a desire to revive the glory of India and resentment for the foreign rule.V.O. Chidambaram stood up to colonial tyranny and oppression in his unique way of Swadeshi and boycott.

Tuticorin, known for its pearl fishery had been a port of importance for several centuries making the Chola and Pandya Kingdoms prosperous in the medieval period. In the modern period, it was an important port with an access to Ceylon. Shipments of cotton from northern Tirunelvelly and beyond were brought to the harbour of Tuticorin, a terminus of the Southern Indian Railway. In 1880, the British entrepreneurs had established Cotton Mills and the Coral Mills. Most famous of them were located in Tuticorin because of its position of vantage both for procuring raw materials and for despatching finished products ${ }^{7}$. The British Indian Steam Navigation Company (BISNCo) conducted the trade with Ceylon

The rising tempo of nationalist activity made the British to reconsider thefeasibility of continuing their lucrative trade through Tuticorin port. They attempted to shift their trading activities from Tuticotin to another port within easy reach of Ceylon and stated the lack of facilities at Tuticorin port as an excuse ${ }^{8}$. The merchants of Tuticorin panicked and approached V.O.Chidambarampillai to safe guard their own commercial interest. On the request of merchants of Tuticorin, V.O. Chidambarampillai initiated steps to break the monopoly of theBritish shipping in the coastal trade with Ceylon and he went to Ceylon and proudly brought back the contracted ship of Shah Line Steamers under the name S.V. Swadeshi Streamers.

Difficulties soon arose in the form of Shah Line merged with the newly-started Shah Steam Navigation Company of India in August, 1906. Meanwhile V.O.Chidambarampillai broughttogether the merchants of Tuticorin and commercial figures from Tirunelvelly, Madurai and other parts of Tamil Nadu and 
established the Swadeshi Steam Navigation Company (SSNCo). It was formally floated on October 16,1906. The company was invested with a capital of Rs.10 lakhs divided in to 40,000 shares of Rupees 25/- each. Indians, Ceylonese and other Asian Nationalist alone were admitted to shareholding, in consonance with nativistic boycott ideology. PandithuraiDevarwas elected as the president of the board with V.O.Chidambarampillai as the secretary and SelamVijayaraghavachariar serving as the legal advisor of the company. "To establish a cheap and reliable steamer service between Tuticorin and Colombo and all such parts and places and to popularise the art of navigation, among Indians, Ceylonese and other Asiatic and to make them profit by it "were some of the lofty objectives of the Swadeshi Steam navigation company".

The spread of Swadeshi Movement in Tamil Nadu led to the emergence of a newparty (Extremists) against the Madras MahajanaSabha which represented the old party of Moderates. When the 14th Madras provincial conference was held at Tirunelvelly in June 1906, leaders of the new party felt themselves excluded and so convened aSwadeshiconference at Palayamcottah where they decided to pursue their own goal of Swadeshism.V.O.Chidambarampillai attended the conference both at Tinnevelly and Palayamcottah and later he gave lectures on Swadeshi in Madurai and Tirunelvelly.

Invited by B.C. Pal and Kaparde to strengthen their hand, the extremists of Tamil Nadu went to Calcutta in December 1906, to attend the annual session of the Indian National Congress and they pledged support to the boycott resolutions ${ }^{10}$. He was convinced that Swadeshi without boycott was meaningless. He even went a step further and declared that not only foreign goods but everything foreign should be boycotted vigorously the inevitable result of which would be the attainment of Swaraj ${ }^{11}$.Thus, the beginning of 1907, found V.O.Chidambarampillai not only as the secretary of the board that controlled the Swadeshi Steam Navigation Company but also an avowed nationalist wedded to Swadeshi and boycott.

Perhaps V.O.Chidambarampillai's conventions of the effectiveness of boycott was directly consequent to the struggle for survival of the Swadeshi Steams in the face of heavy competitions from the British Indian Steam Navigation Company. In spite of the unfair means adopted by the British Indian Steam Navigation Company, the S.V. Swadeshi Streamers were running a profitable business. The change in the ownership of the Shah Line meant that the Swadeshi Steam Navigation Company lost its contract as well as the steamer. Compelled by circumstances, theSwadeshi Steam Navigation Company charted another steamer, Monkseaton, for a while. To be in a position to compete with the British Indian Steam Navigaton Company, however, the Swadeshi Steam Navigation Company required at least one more vessel. The newly formed Shah Steam Navigation Company India Ltd,now offered the services of her steamers Shah Allum and Shah Ameer, provided theSwadeshi Steam Navigation Company entered into a new contract with the company. Unfortunately, the new contract, rather than resolving the problems faced by the Swadeshi Steam Navigation Company, created friction between Shah Steamers and the new Swadeshi Company.

FinallyV.O.Chidambarampillai raised a loan and proceeded to Bombay to negotiate and buy two Ships for the Swadeshi Steam Navigation Company. When V.O.Chidambarampillaiwas thus engaged his eldest son fell ill seriously and his wife was expected a baby at any moment ${ }^{12}$. But V.O.Chidambarampillai trusted God to take care of his pregnant wife and his ailing son. Leaving Tuticorin in December 1906 V.O.Chidambarampillai returned only in April, 1907, in the Gallia which he had purchased along with the Lawoe in Bombay ${ }^{13}$.

In April -May 1907 BipinChandre Pal undertook a tour of South India with the aim of spreading the message of Swadeshi and arrived on April 30, 1907. Between May 1 and May 9, 1907, B.C. Pal delivered as many seven lectures about the concept of Swadeshi, boycott and swaraj to the people assembled on the Marina Beach.V.O.Chidambarampillai's energetic speech and eloquent use of the Tamil language in translating the speeches of B.C Pal had electric effect all over Tamil Nadu.

The extremists, particularly Bharathy and V.O.Chidambarampillai were recommendingto makeLalalajpatRai, as the President of Indian National Congress. Prior to the Suratsession, the young nationalists who had formed a new organisation called the Chennai Jana Sangam, met at the residence of the Mandayam Brothers. Where V.O.Chidambarampillai andSrinivasaChari accepted to share the travel expensesof hundred representatives. At the opening session of the congress on December 26, 1907 the Madras and Deccan delicate, occupying the front rows, did not allow Surendranath Banerjee to address the assembly but loudly called for Tilak and Lajpat Rai ${ }^{14}$. According to V.O.Chidambarampillai,Tilak stood like the powerful but calm lion before a hundred frenzied elephants. V.O.Chidambarampillaiwas selected to act as Secretary for carrying out the work of the new party in the Madras Presidency.

After their returning from SuratBharathi and V.O.Chidambarampillaiwere engaged inactive propaganda regarding the split in the congress and the establishment of the Nationalist Conference and its programme of action. Returning to TuticorinV.O.Chidambarampillai continued his political activities with a renewed vigour.

The Swadeshi Steam Navigation Company was an ambitious attempt with an investment of 10 lakhs of capital. The investors from Calcutta and Bombay had a considerable number of sharesand the response from Madras was not so enthusiastic. The canvassing for shares took V.O.Chidambarampillai to different directions. 
But in the process of promoting the prospects of theSwadeshi Steam Navigation Company Chidambaram incurred the jealousies of the merchants who now wanted him to be removed from the board. V.O.Chidambarampillai never cared for positions and so accepted to serve the Swadeshi Steam navigation company in any capacity. He even travelled to Colombo in order to get shares for the Swadeshi Steam navigation company. As a result of the tireless work undertaken by patriots like VandeMatharamShanmugaSundaramPillai, KalyanasundramIyer, MuthaiyaPillai, KandasamiKavirayar, NatrajIyer and PandithuraiDevar and the support of national leaders like G. SubramanyaIyer who exhorted the people to strengthen the Swadeshi Steam Navigation Company and thus serve the nationalist cause .Shares were sold in good numbers and theSwadeshi Steam navigation company managed very well the face of competition from the British Indian Steam Navigation Company ${ }^{15}$. And those who were jealous of V.O.Chidambarampillai satisfied themselves by sending petitions to the British Governor of Madras about the political activities of Chidambaram.

In 1908,V.O.Chidambarampillaicame into contact with the mystical Subramania Siva, born in Batlagundu in Madurai district, Siva was educated up to the Matriculation level. Siva was a fiery orator in Tamil and an ardent nationalist supporting the cause of Swadeshi . Under the auspices of the DesabhimaniSangam, a Swadeshi organisation based in Tirunelvelly,Subramania Siva delivered moving speeches which attracted V.O.Chidambarampillai. If Siva breathed fire through his speeches, Chidambaram created storms by his eloquence. Drawn together in expanding, expounding and exhorting the message of Swadeshi, Chidambaram and Siva became great friends ${ }^{16}$. This friendship proved later to be life long, weathering adversities, misfortunes, repressions and harassment.

The activities of the agents of the Swadeshi Steam Navigation Company extended its operation to Andhra Pradesh and overseas to Burma and Ceylon. Though initially theSwadeshi Steam Navigation Companychoose to ignore the Swadeshi concern it soon became evident that the latter was a contender forcing the former to retaliatory measures. The British Indian Steam Navigation Company enjoyed the patronage of the bureaucracy and invoked "a range of dubious stratagems to outmanoeuvre and outcompete theSwadeshi Steam Navigation Company". It reduced freight charges and passenger's rates, paid commissions to the railways for attracting more number of passengers and even arranged for travel concessions in the British Indian and Ceylon railways for those who chose the British Indian Steam Navigation Company. But all these measures were of no avail and the Swadeshi Steam navigation company was gaining fast and the British Indian Steam Navigation Company was estimated to lose between Rs. 30000 and Rs. 40000 per month in late 1907 and early $1908^{17}$. As such the bureaucrats in alliances with the British Indian Steam Navigation Company were necessitated to resort to other means to offset the commercial prospect of the Swadeshi Steam Navigation Company. They soon found those means in the political activities of V.O.ChidambaramPillai. In 1908, the crowning success of the Swadeshi enterprise was marked by contrasting tendencies within the Swadeshi Steam Navigation Company. Those whose motives were commercial and who were controlling the Company's board did not want any connection with nationalist politics. They even passed a resolution objecting to the participation in political lectures and demonstrations as; such participations they felt could endanger the prestige and prospects of the Swadeshi Steam Navigation Company ${ }^{18}$. On the other hand, VOC and same of his associates saw the survival of the Swadeshi Company unmistakably linked to the Swadeshi movement and the Nationalist cause.

\section{Labour Unrest and Swadeshi}

The Swadeshi movement not only gave a fillip to the ambitions of the rising Indian capitalist class in the early twentieth century, it was also "Linked up in a powerful way with an incipient still inchoately organized working class movement...." . Particularly in Tamil Nadu, the poor working conditions of the industrial labourers provided perfect ground for breeding anti-imperialist sentiments. Discontentment among the railway workers in Perambur and Nagpattinam led to a number of clashes between Indian and Anglo Indian employees, decidedly due to the spread ofSwadeshism ${ }^{19}$. The drawing of the discontented labour element in to the stream of the nationalist movement was the achievement of V.O.ChidambaramPillai and the occasion for it was provided by the strike of workers in Coral Mills in Tuticorin, in February 1908.

In Tirunelvelly, the British entrepreneurs had established three great spinning mills in the second half of the nineteenth century. These were situated in Papanasem, TuticorinandKoilpatti. The spinning mills and the Coral Mills in Tuticorin employed nearly 1700 workers. Their working day extended from early in the morning, about 5 a.m. to late evening. Labourers spent these long working hours in stuffy, unhealthy atmosphere. No sanitation was providedand there did not exist a full time medical officer. The workers were refused a reasonable salary. In February 1908, labourers of the Coral Mills struck work demanding a legitimate salary and a reduction of working hours.V.O.ChidambaramPillai who had long been interested in labour welfare was quick to take up the cause of the labourers. In order to help the striking labourers he and his friends collected a welfare fund and helped the families of the labourers. Public support in Tuticorin for the labourers increased and almost all sections of the society became involved in the cause of the labourers. The A.F. Harvey brothers, 
proprietors of the Coral Mills were so unpopular with the people that one fine day, while travelling along the Palayamcottahroad; they were pelted with stones by a jeering $\mathrm{mob}^{20}$. The workers of the Madurai Mills, also under Harvey management, launched a sympathy strike on 29 February, 1908, raising the same demands of the Tuticorin Mill hands.

To encourage the labourers to continue their strike with increasing vigour V.O.ChidambaramPillai andSubramania Siva addressed them daily. It is appropriate hereto quote at length the speech made by V.O.ChidambaramPillai on the 3 March, 1908, because it exemplifies the revivalistic and nativisticidealogy of Swadeshi that Chidambram preached to the labourers," why should foreigners purchase our cotton and export it for profit? Why should not we ourselves do so as the cotton is ours and the men who work are our men? Such being the case why should others derive gain from our labour. If two cotton merchants join, our profit will commence from tomorrow forward. We bring our cotton to our town, we do the work, we press it, and then we give the profits to aliens. If four or five cotton merchants unite, it will be very easy to commence the cotton trade and share the profit ourselves. The Swadeshi Steam Navigation Company is already established and has caused loss to the British Indian Steam Navigation Company, which will die away in due course; next to it comes the cotton trade. It is very easy to capture it,I have received letters from several persons from Madurai and Salem intimating that they are willing to invest three fourths of the capital - needed, if the Tutoicorin people help them with the remaining one - fourth and also supply labour. If you people would assist me, I would open a big mill for the manufacture of thread and cloth of all sorts. In Bombay out of 80 Mills, 19 are English concerns and 61 belong to Swadeshis. When our neighbours are ready to assist us why can we not join them and start the enterprise? Are you willing to subscribe and join in the enterprise! It will be a profitable concern. I ask you to give your assent, God will help us. There are two things we should establish a Mill and Press" $"$.

Already V.O.ChidambaramPillai had expressed his desire to bring out a newspaper called Swaraj in Tamil. According to him, a revolution was imminent in India and it was necessary to have a paper to communicate in Tamil what transpired all over India and to propagate to the Tamil people the weapons of Swadeshi and boycott ${ }^{22}$.

On 27 February 1908, the day the workers of the coral Mills began their strike, G.T.H Bracken, Joint Magistrate communicated the message to L.M.Wynch the Collector and District Magistrate, that he immediately need twenty reserve police constables from Tirunelvelly ${ }^{23}$. In addition he issued a notice under section 144 of the Indian penal code to ban the public meetings scheduled to take palace that evening. L.M. Wynch dispatched thirty more reserved police constables from Sivagasi to Tuticorin. To appraise the situation Wynch himself arrived in Tuticorin on 28 February and found the town perfectly quiet.

Despite the ban order, P.S.ShanmugasundaramPillai, a well-known Swadeshi activist and supporter ofV.O.ChidambaramPillai, propagated the intention of V.O.ChidambaramPillai, Siva and PadmanabhaIyengar to address the people in public place and private premises. Immediately V.O.ChidambaramPillaiwas summoned by Bracken in whose office he confronted Wynch also. After prolonged argumentsV.O.ChidambaramPillai made it clear to the officials that he was not only unflinching in his attitude but as a lawyer was also convinced about the legality of his activities. The meetings were conducted in a peaceful manner and after a careful assessment of the situation Wynch and Bracken decided to withdraw the ban order.

The Swadeshi activists in Tuticorin resolved to take out a grand procession on the morning of 9 March to celebrate the release of Bepin Chandra Pal from jail and to hoist the flag of Swaraj. Wynch now became apprehensive and even believed that the situation in Tuticorin placed the European loyalists in a critical position $^{24}$. He felt that the procession scheduled for March 9 should be stopped at whatever cost.ButV.O.ChidambaramPillai and the rest of the Swadeshi activists were engaged in preparation for March 9 celebrations. V.O.ChidambaramPillai was determined to hoist the Swaraj flag on the appointed day even if that meant his death in the hands of the British.

After conferring with the European residents of Tuticorin the new joint magistrate Ashe sent summons for V.O.ChidambaramPillai.V.O.ChidambaramPillai's close friends were afraid that there might be an attempt on V.O.ChidambaramPillai's life. But V.O.ChidambaramPillai was not afraid of his life because he believed that if fate willed him to die nothing could prevent that. Accompanied by his close friend and a lawyer, Mahadevan,V.O.ChidambaramPillai met Ashe. Ashe tried to frightenV.O.ChidambaramPillai by the strength of the police force. ButV.O.ChidambaramPillai was impossible to defeat ever and returned after a wordy exchange with Ashe.

The management of the Coral Mills, at the end of seven days of continuous workers strike finally agreed to give some concessions and sent their agent SubramaniaPillai to negotiate with V.O.ChidambaramPillai. Conditional to certain concessionsV.O.ChidambaramPillai advised the labourers to withdraw their strike and resume their work. However, the Coral Mill strike was brought up for discussion in the Governor-in-Council. The Council suggested "action against Chidambaram Pillai" under section 84 of the 
Criminal Proceedings Code ${ }^{25}$. It wasalso decided to give a freehand to Wynch by approving any action he might take to deal with the situation.

The anti-British activities of V.O.ChidambaramPillai created a panic among the members of the Swadeshi Steam navigation company. They now approached VOC and asked him to give up his political work because by incurring the wrath of the British government he was inviting the ruin of the Swadeshi Steam Navigation Company. But Chidambaram did not budge an inch from his stand against the British. He even came forward to resign his position from theSwadeshi Steam navigation company but never to stop his involvement in the nationalist movement.On the evening of March 8, 1908,V.O.ChidambaramPillai, Siva and Padmanabhalyengar, received show cause notices from Wynch, requiring them to appear before the District Magistrate in Tirunelvelly on 9 March.

During the proceedings, they sought adjournment of the trail for a month to allow them time for the admission of an application in the high court for the transfer of the case from the District Magistrate's Court. Wynch demanded security for the good behaviour of the three leaders during the adjournment. Initially the patriots refused to offer any security. However, later when they actually were ready to offer the security, Wynch rejected the offers deliberately. Later that eveningV.O.ChidambaramPillai, Siva and Padmanabha participated in celebrations marking the release of B.C. Pal, organised in Tirunelvelly town. The next day they took part in the procession and demonstrations in Tuticorin. They again appeared before Wynch on the afternoon of $10 \mathrm{March}$. After two days of prolonged hearing finally Wynch, determined not let go of the chief agitators, remanded them to the District jail adjourning hearing until 1 April $^{26}$.

V.O.ChidambaramPillai, Siva and PadmanabhaIyengarwere arrested on 12 March 1908. They were charged with sedition under section 124A and 153A of the Indian Penal Code. Chidambaram Pillai applied to the high court for fifteen days bail. Wynch refused bail to V.O.ChidambaramPillai, because he feared that if V.O.ChidambaramPillaiwas sent to Tuticorin the people would not allow the police to arrest him again. Arther Franklin Pinhey, Madurai sessions Judge was said to have remarked that even V.O.ChidambaramPillai's bone and skull also would do anti propaganda against the ruling authority ${ }^{27}$.

What followed the arrest of the leaders in Tirunelvelly was the total disruption of peace and order on 13 March. They were angry and so reacted violently. The situation was brought under control by the use of brutal force. They expressed that its success or failure will not affect Tuticorin and its neighbourhood alone; it has become an all- India concern. If at all public support was forthcoming, it was slow and inadequate. Finally, after two years of nominal existence theSwadeshi Steam Navigation Company officially ceased to exist on July 4, 1911. The two ships were sold to the British Indian Steam Navigation Company.

\section{The Trial And Imprisonment}

V.O.ChidambaramPillai ,Subramaia Siva and PadmanabhaIyengarwere arrested on 12 March 1908. They were charged with sedition under section $124 \mathrm{~A}$ and $153 \mathrm{~A}$ of the Indian Penal Code. V.O.ChidambarmPillai was the first Indian to punished for life on a charge of sedition ${ }^{28}$. After a few days of confinement in Palayamcottahjail he was transferred to Coimbatore jail. He gave a message to the people before he was taken to Coimbatore, he said "I will come back very soon but you should not forget Swadeshism and you should not erase the word Swadeshism from your mind. It is our life and breath, one day we shall get freedom from the British rule ${ }^{29}$.

In the prison, he was used as a bullock in pulling the oil press "ckekku" and his right leg was chained in the cruel hot $\operatorname{sun}^{30}$. Thus, he was tortured in a brutal and inhuman manner, later the high court reduced his sentence and he was finally released on December 12, 1912. After his release from jailV.O.Chidambarampillai refrained from political activities though he continued to be a member of the Indian National Congress. Even that connection was lost when he resigned from it in 1920. He fell ill and passed away on November 18,1936, but the passion for freedom still ranging in his mind till the last moment of his death.

\section{Conclusion}

The ideology of Nationalism became an effective weapon in the twentieth century for the Indians to fight colonial tyranny and oppression. Swadeshienterprise symbolised for V.O.ChidambaramPillai the revival of the maritime glory of India andexcellent opportunity to prove that the British were not needed in India.

In the year $1906-1908$, Tirunelvelly district and the natural port city of Tuticorin emerged as important centres of nationalist mobilization focussed on Swadeshi initiatives. The SwadeshiSteam Navigation Company has posed direct challenge to an established British Enterprise. The fortunes of theSwadeshi Steam navigation company would mirror those of the larger political movement in Tamil Nadu and all over India. V.O. Chidambaram Pillai,recognised the important of the fledgling working class to India's National Movement.However the rose of colonial oppression and internal weakness led to disappear the Swadeshi Steam Navigation Company. Even though the anti-colonial spirit that so characteericed the Swadeshi movement in Tirunelvelly was not so easily crashed and certainly never forgotten. 
The images of struggle and national assertiveness left behind by V.O. Chidambaram Pillai and his talented lieutenants would continue inspire the people of Tamil Nadu. Perhaps V.O.ChidambaramPillai 's vision and ideology was prior in advance of his time. His dreams were realised and his prophetic visions were fulfilled much later not in a subject India but in an independent India. Indeed, it was got that the first Indian ship set to sail in the Indian Ocean was named "Chidambaram" in honour of V.O. Chidambaram Pillai the Tamil, who dared to launch a Swadeshi ship in the days of British colonialism. And the port of Tuticorin has also named"Chidambaram".

\section{References}

[1]. T.N.Vallinayagam, CekkiluthaChemmal Chidambaram.International Institute of Tamil Studies, Madras, 1985,p.10

[2]. B.G. Varma,Remembering Our Leaders. New Delhi: Children's Book Trust, 1990,p.66.

[3]. International Encyclopaedia of Social Science, 1972 ed.

[4]. R.A. Badmanaban, BharathiaipatiryNanbargal. VanathiPathipagam, Madras, 1982, p.20.

[5]. VOC, Subramanian, Camp., VOC KandaBarathi. Madras Primeier Co., Madras, 1946, p.7.

[6]. V.O. Chidambaram Pillai,Suyasarithai. Rpt. of the 6th ed. Madras: The Indian Siva Sithanta works Publishing Society, Tinnevelly Ltd.,1990, p.41.

[7]. N.Rajendran, National Movement in Tamil Nadu.Oxford University Press, 1994, p.86.

[8]. M.Krishnaswami, Biography of VOC. Hariharan Press, Madras, 1908, p.18.

[9]. 'Swadeshi Steam Navigation Company, Tuticorin, File'. Public Miscellaneous Bundle No. 35, p.7-8, Tamil Nadu Archives.

[10]. India, 22 December 1906.

[11]. N.Rajendran, National Movement in Tamil Nadu.Oxford University Press, 1994, p.38.

[12]. T.N. Vallinayagam,CekkiluthaChemmal Chidambaram. International Institute of Tamil Studies, Madras, 1985 , p.32.

[13]. V.O. Chidambaram Pillai,Suyasarithai. Rpt. of the 6th ed. The Indian Siva Sithanta works Publishing Society, Tinnevelly Ltd., Madras, 1990, p.55-56.

[14]. A.C. Mazundar, Indian National Evolution. G.A. Natesan, Madras, 1915, p.116.

[15]. N.Rajendran, National Movement in Tamil Nadu. Oxford University Press, 1994, p.89-90.

[16]. T.N Vallinayagam,CekkiluthaChemmal Chidambaram, International Institute of Tamil Studies, Madras, 1985 , p.39.

[17]. Ibid.

[18]. 'The Tinnevelly and Tuticorin Deputation', Public Miscellaneous Bundle No 29, Tamil Nadu Archives.

[19]. Unrest in the Madras Presidency File', Vol. II, part II and I.

[20]. Madras Secret Police Abstracts of Intelligence 1908, Para 297, p.169.

[21]. G.O. No. 1542, Judicial, dated 3rd October.

[22]. 'Tinnevelly Riots', Select Documents, Vol.3, p.10, Tamil Nadu Archives.

[23]. 'Tnnevelly Riots', Public Miscellaneous Bundle No. 43, p.3 Tamil Nadu Archives.

[24]. 'Tnnevelly Riots', Public Miscellaneous Bundle No 43, p.67.

[25]. Sedition in Tinnevelly, Public Miscellaneous Bundle, No.43, p.3, 1908, Tamil Nadu Archives.

[26]. N. Rajendran, The National Movement in Tamil Nadu. Oxford University Press, 1994,p.98.

[27]. Annamalai, M.VaralatrilSilaAthisayangal. MarudhaMalaiyanPathipagam, Madras, 1985,p.78.

[28]. S.P. Sen,Dictioanary of National Biography, 3rd Vol. Institute of Historical Studies, Culcatta, 1974,p.8.

[29]. T.N. Vallinayagam,CekkiluthaChemmal Chidambaram. International Institute of Tamil Studies, Madras, 1985 , p.72-73.

[30]. Ibid. 